\title{
Genetic Distance and Diversity in Table Beet and Sugar Beet Accessions Measured by Randomly Amplified Polymorphic DNA
}

\author{
Min Wang ${ }^{1}$ \\ U.S. Department of Agriculture, Agricultural Research Service, Vegetable Laboratory, 2875 Savannah \\ Highway, Charleston, SC 29414-5334 \\ Irwin L. Goldman ${ }^{2}$ \\ Department of Horticulture, 1575 Linden Drive, University of Wisconsin, Madison, WI 53706
}

AdDitional INDEX wORDs. red beet, RAPD marker, genetic distance, multidimensional scaling

\begin{abstract}
Aвstract. Genetic relationships among 37 accessions of Beta vulgaris, including 21 table beet, 14 sugar beet, and two Swiss chard (Beta vulgaris ssp. cicla) accessions, were evaluated using randomly amplified polymorphic DNA (RAPD). Genetic distance was estimated based on the presence or absence of polymorphic RAPD bands. Multidimensional scaling plots of genetic distance values revealed that table beet inbred lines from the University of Wisconsin Table beet Breeding Program clustered in an intermediate position between sugar beet breeding lines and standard table beet germplasm, likely because of their origin from an introgression program designed to incorporate sugar beet genes.
\end{abstract}

Beta L. is an Old World genus in the Chenopodiaceae. Both sugar beet and table beet belong to Beta vulgaris, ssp. vulgaris. Swiss chard belongs to Beta vulgaris ssp. cicla. (Ford Lloyd, 1995 ). Sugar beet has been cultivated for $\approx 200$ years and is a major source of world sugar production (Smith, 1987). Table beet and Swiss chard are consumed as vegetables throughout the world. Despite the close relationships among these cultivated forms, little genetic information has been presented to describe variation among and within cultivated accessions.

Wild beet plants have been found in the Mediterranean regions, Asia Minor, the Caucasus, and the Near East. Table beet originated as a leaf vegetable or potherb in the Mediterranean, spreading eastward in ancient times, with a secondary region of development in the Near East. Early description of chard was given by Aristotle and Theophrastus (Ford Lloyd, 1995). Selection for the swollen-rooted character likely happened as the cultivated leaf beet moved into northern Europe. The modern table beet with a swollen root was first described as a food plant in Germany in 1558 . Up to $\approx 1800$, only two table beet cultivars, Red and Long Red, were listed in European seed catalogs. Sugar beet, on the other hand, was developed during the 18th century as independent sources of sugar were sought for Europe. Selection of sugar beet from fodder beet and leaf beet progenitors has been described (Fischer, 1989).

The genetic relationship between sugar beet and table beet has been estimated by several researchers. Morphological traits including growth habit, mode of branching, leaf shape, leaf color, reproductive system, and ploidy level have resulted in the classification of the genus Beta into four sections (Beta, Corollinae, Nanae, and Procumbens). Genetic relationships among the 15 species in these sections, however, have not been clearly elucidated (Buttler, 1977; Frese and van Hintum, 1989). Recently,

Received for publication 11 Jan. 1999. Accepted for publication 9 Aug. 1999. The cost of publishing this paper was defrayed in part by the payment of page charges. Under postal regulations, this paper therefore must be hereby marked advertisement solely to indicate this fact.

${ }^{1}$ Former postdoctoral research assistant.

${ }^{2}$ Associate professor. To whom correspondence and reprint requests should be addressed; email: ilgoldma@facstaff.wisc.edu. molecular markers have been used to assess genetic relationships among Beta species (e.g., Shen et al., 1996).

Isozyme polymorphism indicated significant differences between fodder beet and sugar beet, but not between monogerm sugar beet and multigerm sugar beet (Nagamine et al., 1989a). Restriction fragment length polymorphism (RFLP) analyses showed large amounts of genetic variability between cultivars within Beta vulgaris (Mita et al., 1991; Nagamine et al., 1989b). Restriction profiles of chloroplast and mitochondrial DNA revealed identical restriction patterns for fodder beet, table beet, leaf beet, Swiss chard and sugar beet, with the exception of sugar beet with S-cytoplasm (Ecke and Michaelis, 1990). Restriction patterns of plastid DNA differed between three wild species in the genus Beta and cultivated Beta vulgaris, and were identical for cultivars and lines of Beta vulgaris despite their strong morphological variation. DNA fingerprinting revealed low genetic similarities (GS) between sugar beet and other wild species and between fodder beet and sugar beet or table beet in section Beta, but high GS among sugar beet cultivars and breeding lines have been observed (Jung et al., 1993). Knowledge of genetic variability patterns among cultivated sugar beets and table beets should provide breeders with valuable information regarding genetic similarity of individuals in breeding populations.

An interesting aspect of most table beet breeding programs has been their recent reliance on genes from sugar beet. Four of the main traits used in modern table beet breeding: sterile cytoplasm (Owen, 1945), self-fertility, monogerm seed (discussed in McFarlane, 1993), and the annual growth habit (Abegg, 1936) were incorporated from sugar beet via backcrossing (Goldman, 1996). Despite more than 10 backcross generations used to eliminate linkage drag, some of the table beet germplasm possesses characteristic sugar beet traits, such as external russeting and enlarged crowns. With this historical framework in mind, we became interested in assessing genetic diversity among accessions of table beet germplasm derived from crosses with sugar beet, table beet germplasm derived solely from table beet progenitor populations, and modern sugar beet germplasm.

Randomly amplified polymorphic DNA (RAPD) markers have been used successfully as a tool for estimating genetic 
Table1. Table beet and Swiss chard accessions sampled for RAPD analysis in Study 1.

\begin{tabular}{|c|c|c|c|}
\hline Accession & Sample no. & Type & Origin \\
\hline Large White Ribbed & 6 & Swiss chard & Chriseed (U.S.) \\
\hline Polish Egyptian & 7 & Table beet $(\mathrm{OP})^{\mathrm{z}}$ & Bejo (Holland) \\
\hline Detroit Medium Top & 5 & Table beet (OP) & Chriseed (U.S.) \\
\hline Fordhook Giant & 5 & Swiss chard & Chriseed (U.S.) \\
\hline Polish Dark Red & 5 & Table beet (OP) & PNOS (Poland) \\
\hline Kosak & 2 & Table beet (OP) & Hammenhogs (Germany) \\
\hline Albina Verduna & 8 & Table beet (OP) & Territoria (U.S.) \\
\hline Half Long Cylindrical & 5 & Table beet (OP) & Daehnfeldt (Denmark) \\
\hline Boltardy & 4 & Table beet (OP) & WW Johnson (U.K.) \\
\hline Forono & 3 & Table beet (OP) & Daehnfeldt (Denmark) \\
\hline Cardenal & 4 & Table beet (OP) & Rispens (U.S.) \\
\hline Formanava 1 & 6 & Table beet (OP) & Veseys (Canada) \\
\hline Formanava 2 & 4 & Table beet (OP) & Veseys (Canada) \\
\hline Lutz Greenleaf & 3 & Table beet (OP) & Chriseed (U.S.) \\
\hline Crosby Green Top & 4 & Table beet (OP) & Chriseed (U.S.) \\
\hline Detroit Supreme & 3 & Table beet (OP) & Chriseed (U.S.) \\
\hline Ruby Queen 1 & 6 & Table beet (OP) & Chriseed (U.S.) \\
\hline Ruby Queen 2 & 2 & Table beet (OP) & Northrup King (U.S.) \\
\hline $\mathrm{W} 425 \mathrm{~B}$ & 2 & Table beet (inbred) & UW-Madison ${ }^{y}$ \\
\hline W427B & 3 & Table beet (inbred) & UW-Madison \\
\hline W431B & 9 & Table beet (inbred) & UW-Madison \\
\hline W438B & 6 & Table beet (inbred) & UW-Madison \\
\hline
\end{tabular}

${ }^{\mathrm{z}} \mathrm{OP}=$ open-pollinated.

yUW-Madison = University of Wisconsin, Madison.

relationships in many crop species, including Brassica oleracea L. (cabbage) (dos Santos et al., 1994); Phaseolus vulgaris L. (bean) (Beebe et al., 1995; Skroch and Nienhuis, 1995; Skroch et al., 1992); Solanum L. sp. (Spooner et al., 1995) and Cynara scolymus L. (globe artichoke) (Tivang et al., 1996). In this investigation, RAPD markers were used to assess genetic relationships among Beta vulgaris accessions in two independent studies. The objective of Study 1 was to assess genetic diversity among a diverse group of table beet accessions from around the world. The objectives of Study 2 were to determine genetic distance and diversity among and within sugar beet breeding populations and estimate genetic distance with two table beet accessions.

\section{Materials and Methods}

Plant Germplasm. In Study 1, 20 table beet accessions (16 open-pollinated cultivars and four inbred lines) and two openpollinated Swiss chard accessions were used (Table 1). The openpollinated cultivars were chosen to represent a broad range of table beet germplasm throughout the world. The inbred lines were developed at the University of Wisconsin Table beet Breeding Program by W.H. Gabelman using sugar beet as a distant parental source of several important genes (Goldman, 1996). In Study 2, 14 randomly selected sugar beet breeding lines commonly used in hybrid production in the sugar beet breeding program at American Crystal Sugar, Moorehead, Minn., and two table beet accessions, the $\mathrm{F}_{1}$ hybrid 'Red Ace' and the inbred line W425B, were used (Table 2). 'Red Ace' is a hybrid constructed in part from an inbred line from the University of Wisconsin Table Beet Breeding Program.

Plant dna ISOlation. DNA was extracted from fresh leaves of 3-week-old individual beet seedlings according to the method of Skroch and Nienhuis (1995). Two to nine individual DNA samples from each of 22 accessions in Study I and six individual DNA samples from each of 16 accessions in Study 2 were used in this investigation.

Primer Selection. Individual DNA samples were evaluated using a range of RAPD primers before initiation of this investigation. Based on the consistency and clarity of polymorphic bands, Operon (Alameda, Calif.) primers AA04, AB11, AC20, AE07, and AF11 were selected for Study 1, and AA03, AA10, AA12, AA14, AB01, AB09, AB11, AB17, AB18, AC07, AC15, AC19, AC20, AD02, AE07, AE08, AE09, AF11, AF14, AI04, and AI17 were selected for Study 2. Additional primers were chosen for Study 2 in an effort to characterize more fully within-accession variation.

Table 2. Sugar beet breeding lines and table beet accessions sampled for RAPD analysis in Study 2.

\begin{tabular}{lcl}
\hline \hline Accession & Sample no. & Type \\
\hline ACS7900923 & 6 & Sugar beet (BL) \\
ACS8300047 & 6 & Sugar beet (BL) \\
ACS8700691 & 6 & Sugar beet (BL) \\
ACS8800705 & 6 & Sugar beet (BL) \\
ACS8900011 & 6 & Sugar beet (BL) \\
ACS8900245 & 6 & Sugar beet (BL) \\
ACS9090346 & 6 & Sugar beet (BL) \\
ACS9100128 & 6 & Sugar beet (BL) \\
ACS9100168 & 6 & Sugar beet (BL) \\
ACS9100209 & 6 & Sugar beet (BL) \\
ACS9100272 & 6 & Sugar beet (BL) \\
ACS9200067 & 6 & Sugar beet (BL) \\
ACS9300176 & 6 & Sugar beet (BL) \\
ACS9400461 & 6 & Sugar beet (BL) \\
W425B & 6 & Table beet (Inbred) \\
Red Ace & 6 & Table beet (F) \\
\hline
\end{tabular}

${ }^{\mathrm{z}} \mathrm{BL}=$ breeding line. 


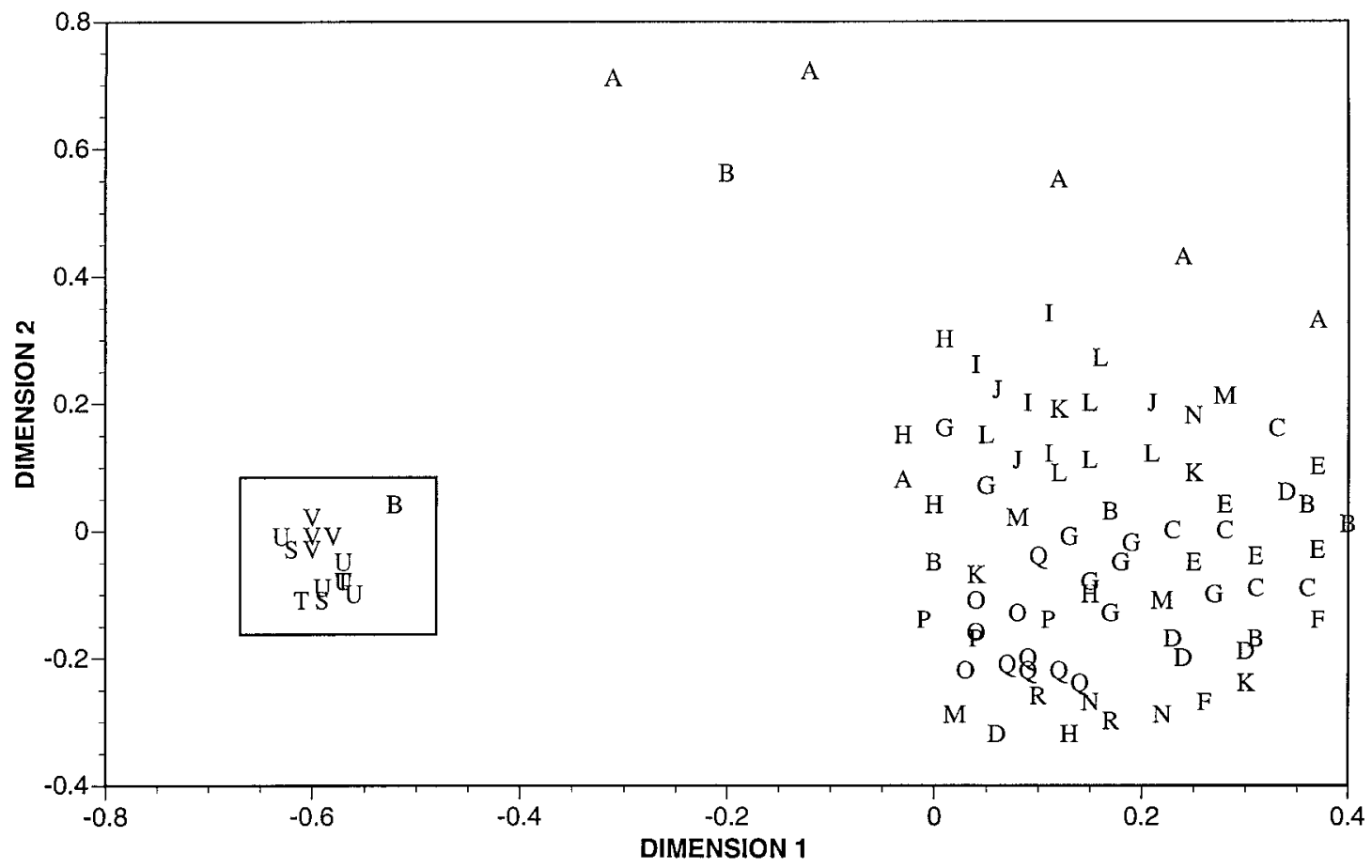

\begin{tabular}{|cllllll|}
\hline A & 'Large White Ribbed' & G 'Albina Verduna' & M & 'Formanava 2' & R 'Ruby Queen 2' \\
B 'Polish Egyptian' & H & 'Half Long Cylindrical' & N & 'Lutz Greenleaf' & S & W425B \\
C 'Detroit Medium Top' & I & 'Boltardy' & O 'Crosby Green Top' & T & W427B \\
D 'Fordhook Giant' & J 'Forono' & P 'Detroit Supreme' & U W431B \\
E 'Polish Dark Red' & K 'Cardenal' & Q 'Ruby Queen 1' & V W438B \\
F 'Kosak' & L 'Formanava 1' & & & \\
\hline
\end{tabular}

Fig. 1. Relationship among table beet and Swiss chard accessions using two dimension coordinates from multidimensional scaling (MDS) analysis. Multiple individuals of a single accession are indicated separately by multiple occurrences of a single letter. The rectangle indicates the cluster of inbred line accessions from the University of Wisconsin Table beet Breeding Program.

RAPD ANALYSIS. Each individual DNA isolation was used as a template for polymerase chain reaction (PCR) amplification. Reactions were run in 96-well assay plates. The PCR protocol was as described by Eagen and Goldman (1996) and modified to include $0.2 \%$ bovine serum albumin (BSA) in each reaction. Controls containing no template DNA were conducted with each reaction plate. The reactions were performed in a Thermal Controller (MJ Research, Boston, Mass.) programmed for 42 cycles after initial denaturation for $60 \mathrm{~s}$ at $94^{\circ} \mathrm{C}$. Each cycle consisted of $30 \mathrm{~s}$ at $92^{\circ} \mathrm{C}, 60 \mathrm{~s}$ at $36^{\circ} \mathrm{C}$, and $60 \mathrm{~s}$ at $72^{\circ} \mathrm{C}$. The amplification fragments were separated by electrophoresis on $1.6 \%$ agarose gels, stained with ethidium bromide, and photographed under ultraviolet light. A 100-base-pair ladder was used as a molecular weight standard on each gel. The sizes of amplified fragments ranged from 200 to 2000 base pairs. Polymorphic bands were classified as present or absent.

Genetic Distance. A genetic distance (GD) matrix was completed using a program developed by P.W. Skroch (Skroch et al., 1992, Skroch and Nienhuis, 1995). Estimates of GD were calculated for all 102 individual samples in Study 1 and all 96 individual samples in Study 2 based on the complement of the simple matching coefficient (Gower, 1972), given as GD $(i, j)=$ $\sum \mathrm{N}(\mathrm{i} \neq \mathrm{j}) /\left[\sum \mathrm{N}(\mathrm{i} \neq \mathrm{j})+\right.$ $[S N(i=j)]$, where GD is the measure of genetic distance between entry $\mathrm{i}$ and $\mathrm{j}$, while $\left[\sum \mathrm{N}\right.$ $(\mathrm{i} \neq \mathrm{j})$ and $\sum \mathrm{N}(\mathrm{i}=\mathrm{j})$ are the total number of discordant and concordant sources between entry $\mathrm{i}$ and $\mathrm{j}$, respectively, for all $\mathrm{N}$ bands. A GD value of 0.0 and 1.0 indicates no and maximal RAPD difference between two entries, respectively.

The $102 \times 102$ triangular matrix of GD values in Study 1 and the 96 $\times 96$ triangular matrix of GD values were analyzed by unweighted classical multidimensional scaling (MDS) and displayed as a two dimensional MDS plot (Young and Hamer, 1987). In Study 2, variance analysis for GD estimates was performed using the analysis of molecularvariance (AMOVA).F test modified from the AMOVA was used to test the significance of differences among and within the 16 accessions (Excoffier et al., 1992; Long, 1986). Comparisons of genetic distance and mean number of polymorphic RAPD bands per primer among accessions were determined separately by one-way analysis of variance.

\section{Results}

RAPD POLYMORPHISM. In Study 1, the number of polymorphic bands per primer ranged from 6 to 12, resulting in a total of 42 polymorphic bands. In Study 2, the number of polymorphic bands per primer ranged from 2 to 13 , resulting in a total of 201 polymorphic bands. At least one polymorphic RAPD band was found for all 4560 parity comparisons of individual samples. The F value of 9.92 for mean number of polymorphic bands per primer indicated significantly $(P=0.0006)$ different levels of polymorphism within the 16 accessions in Study 2. The mean number of polymorphic bands scored per primer ranged from three to five for all sugar beet populations whereas the table beet accessions W425B and 'Red Ace' had less than one polymorphic band per primer.

GeNeTIC Relationship ReVEaled BY MDS. The genetic relationships among 22 accessions in Study 1 and among 16 accessions in Study 2 were displayed in two 2-dimensional MDS plots, respectively (Figs. 1 and 2, respectively). The $R^{2}$ values for the proportion of variation explained by the two dimensional MDS were $98 \%$ and $95 \%$ for Study 1 and Study 2, respectively, which indicates a good fit between the two dimensional representation 


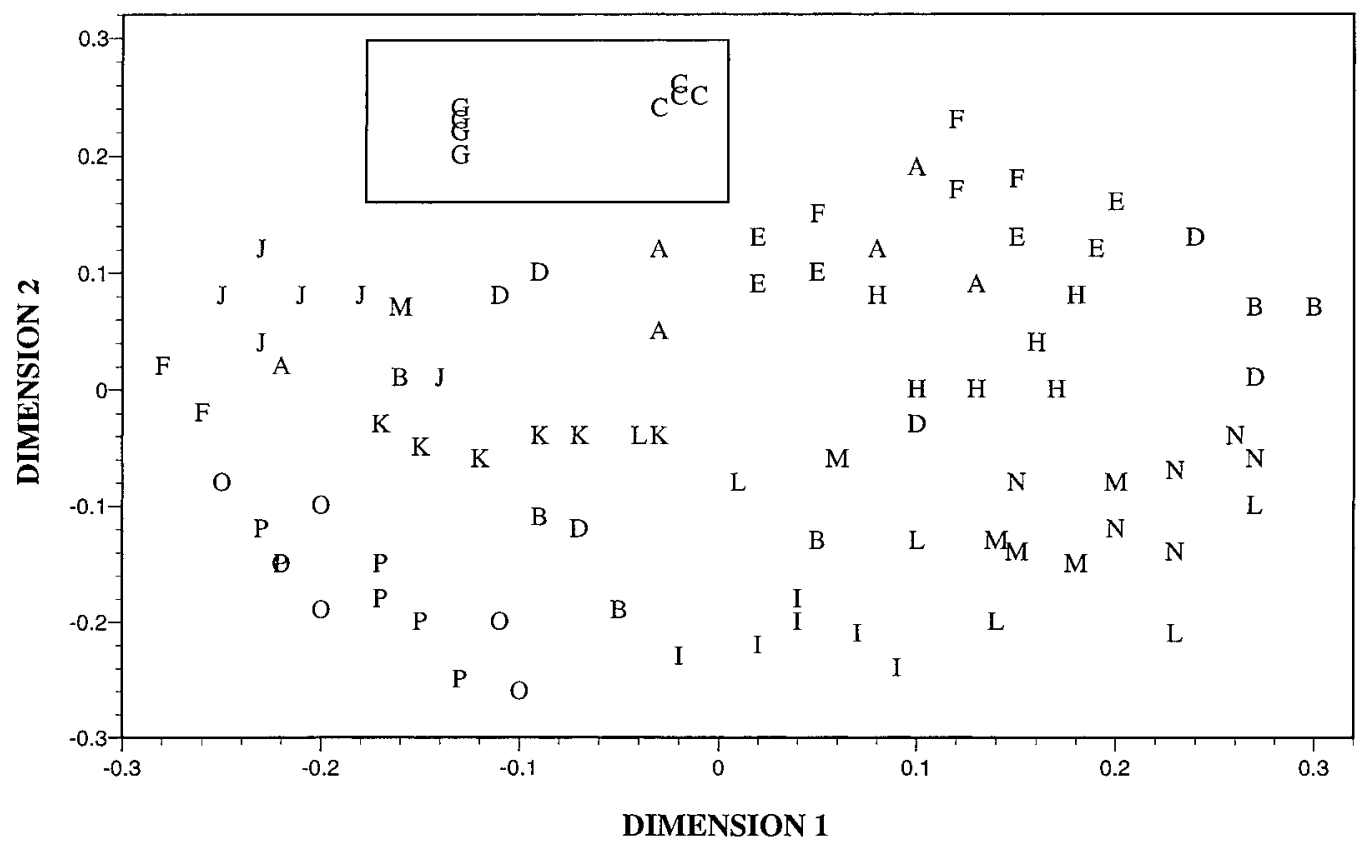

\begin{tabular}{|llllllllllllll|}
\hline A & 8800705 & D & 9100128 & G & W425 & I & 9300176 & K & 7900923 & M & 8300047 & O & 9200067 \\
B & 9090346 & E & 8900245 & H & 8700691 & J & 9100168 & L & 9100209 & N & 9100272 & P & 9400461 \\
C & 'Red Ace' & F & 8900011 & & & & & & & & & & \\
\hline
\end{tabular}

different from seven sugar beet accessions, but not significantly different from each other. Nonsignificant deviations in genetic distance within accessions were observed for the two table beets, W425 and 'Red Ace', along with four of the sugar beet accessions (Table 4). The remaining sugar beet accessions exhibited significant or highly significant withinaccession deviations in genetic distance.

\section{Discussion}

The primary finding of Study 1 was the distinct clustering of table beet inbred lines from the University of Wisconsin Table beetBreeding Program and open-pollinated table beet cultivars (Fig. 1) Since there are no publicly available inbred lines of table beet, other than those from the University of Wisconsin, it was not possible to examine whether proprietary inbred lines also exhibit a unique pattern of genetic distance with respect to

Fig. 2. Plot of relationship among sugar beet and table beet accessions by two dimension coordinates from a multidimensional scaling (MDS) analysis. Multiple individuals of a single accession are indicated separately by multiple occurrences of a single letter. The rectangle indicates a cluster of 'Red Ace' and W425 individuals.

of relationships among accessions and the original genetic distance matrix.

The four table beet inbred lines W425B, W427B, W431B, and $\mathrm{W} 438 \mathrm{~B}$ grouped together in a tight cluster and were distant from the open-pollinated table beet and Swiss chard accessions (Fig. 1). The open-pollinated table beet and Swiss chard accessions overlapped in a single loose cluster. Within this cluster, three smaller clusters were visible: one containing 'Detroit Medium Top' and 'Polish Dark Red', another containing 'Boltardy', 'Forono', and 'Formanova', and a third with 'Crosby Green Top', 'Detroit Supreme', and both 'Ruby Queen' accessions. 'Polish Egyptian' exhibited a large amount of internal variability and was scattered over the entire plot. In general, individuals within an accession grouped together, with the exception of 'Polish Egyptian' and 'Large White Ribbed'.

In Study 2, sugar beet accessions ACS8700691, ACS9100272, ACS9300176, ACS7900923, and ACS9100168 formed five discrete clusters, respectively. ACS9200067 and ACS9400461 clustered together. The remaining six sugar beet accessions ACS9100209, ACS9090346, ACS9100128, ACS8900011, ACS8800705, and ACS8300047 were scattered around the six clusters. W425B and 'Red Ace' formed two individual tightly closed clusters, separated from the sugar beet clusters.

Results from the AMOVA in Study 2 showed highly significant $(P<0.0001)$ variation among the 16 accessions. ACS9090346 had the highest mean genetic distance (0.327) and ACS7900923 had the lowest (0.281) (Table 3). W425 (0.315) and 'Red Ace' $(0.314)$ were in the middle of the range and were significantly standard table beet germplasm. The large gap in genetic distance between inbred lines derived, in part, from sugar beet and standard table beet germplasm may have been caused by linkage drag from genes introgressed into table beet from sugar beet during the 1950s and 1960s (Goldman, 1996). Characters such as monogerm seed $(\mathrm{mm})$, self-fertility $\left(S^{F}\right)$, cytoplasmic male sterility $(S x x z z)$, and the annual growth habit $(B B)$ were all incorporated into modern table beet inbred lines in the University of Wisconsin Table beet Breeding Program. Because this program was initiated with standard table beet germplasm such as 'Detroit Dark Red', it is unlikely that genetic drift in this program could have resulted in such dramatic

Table 3. Comparisons of mean genetic distance among 16 accessions of Beta vulgaris, ranked from highest to lowest.

\begin{tabular}{lc}
\hline Accession & Mean genetic distance \\
\hline ACS9090346 & 0.327 \\
ACS9400461 & 0.323 \\
ACS9200067 & 0.320 \\
ACS9100128 & 0.320 \\
ACS9100272 & 0.319 \\
ACS8900011 & 0.319 \\
ACS9100168 & 0.317 \\
W425 & 0.315 \\
Red Ace & 0.314 \\
ACS9100209 & 0.307 \\
ACS9300176 & 0.305 \\
ACS8700691 & 0.302 \\
ACS8300047 & 0.302 \\
ACS8900245 & 0.297 \\
ACS8800705 & 0.297 \\
ACS7900923 & 0.281 \\
LSD & 0.05 \\
\hline
\end{tabular}


Table 4. Mean squared deviation from the analysis of molecular variance (AMOVA) for genetic distance within each of 16 accessions of Beta vulgaris.

\begin{tabular}{lcc}
\hline \hline Accession & df & MSD $^{\mathrm{z}}$ \\
\hline ACS9100209 & 5 & $0.057^{* * * * *}$ \\
ACS9090346 & 5 & $0.033^{* * * * *}$ \\
ACS9100128 & 5 & $0.033^{* * * *}$ \\
ACS8900011 & 5 & $0.024^{* * * * *}$ \\
ACS8800705 & 5 & $0.024^{* * * * *}$ \\
ACS8300047 & 5 & $0.023^{* * * * *}$ \\
ACS9100272 & 5 & $0.023^{* * * * *}$ \\
ACS8900245 & 5 & $0.017^{* *}$ \\
ACS9300176 & 5 & $0.014^{* * *}$ \\
ACS7900923 & 5 & $0.014^{* * *}$ \\
ACS8700691 & 5 & $0.011^{\mathrm{NS}}$ \\
ACS9200067 & 5 & $0.010^{\mathrm{NS}}$ \\
ACS9400461 & 5 & $0.007^{\mathrm{NS}}$ \\
ACS9100168 & 5 & $0.006^{\mathrm{NS}}$ \\
W425 & 5 & $0.007^{\mathrm{NS}}$ \\
Red Ace & 5 & $0.001^{\mathrm{NS}}$ \\
\hline${ }^{\mathrm{z} M e a n ~ s q u a r e d ~ d e v i a t i o n ~ i n ~ A M O V A ~ i s ~ e q u a l ~ t o ~ t h e ~ c o n v e n t i o n a l ~ m e a n ~}$ \\
square in analysis of variance (Excoffier et al., 1992). \\
Ns,******* Nonsignificant or significant at $P<0.01$ or 0.0001, respectively.
\end{tabular}

shifts in genetic distance. However, loss of allelic diversity through inbreeding, which would certainly have been possible via incorporation of the $S^{F}$ gene, should not be ruled out as a possible explanation for the genetic distance between the groups measured in this investigation.

The two Swiss chard accessions, 'Large White Ribbed' and 'Fordhook Giant', were more closely related to table beet germplasm than to the four table beet inbred lines. However, individual plants of 'Large White Ribbed' were highly heterogenous, suggesting either contamination of this population or a very broad genetic base. Clustering of the Swiss chard cultivars with the standard table beet germplasm reveals similarities in leaf beet populations which might have been present since the origin of these crops in the Mediterranean region.

Distribution of the cluster and scattering patterns in the MDS plot of Fig. 2 shows the genetic uniformity and diversity among and within table beet and sugar beet. The accessions 'Red Ace', W425B, ACS9100168, ACS9400461, ACS9200067, and ACS8700691 each exhibited its own cluster in the MDS plot and nonsignificant variation within each population. The low level of variation within these populations is consistent with the nature of these cultivars. Hybrid cultivars of table beet, formed from crosses of pairs of inbred lines, would be expected to possess high levels of genetic uniformity. The same would be expected for inbred lines of table beet, which were developed through use of the self-fertility allele $\left(S^{f}\right)$ incorporated from sugar beet. Separation of these clusters suggests significant variability across table beet and sugar beet breeding populations. These findings also suggest an important influence of breeding practices such as self-pollination on genetic similarity of breeding populations, since sugar beet breeding programs generally do not use the $S f$ allele, while table beet breeders have used this allele for direct selfing. Finally, 'Red Ace' is constructed from a parent derived from the University of Wisconsin Table beet Breeding Program. Even though W425 is not a parent of 'Red Ace', it exhibits some genetic similarity, based on pedigree, to the inbred line used in 'Red Ace'. Therefore it is not surprising that 'Red Ace' and W425 clustered in close proximity.
The populations ACS9100209, ACS9090346, ACS9100128, ACS8900011, ACS8800705, and ACS8300047, were broadly scattered in the MDS plot and showed the most significant $(P<$ $0.0001)$ variation within each population. These results indicate that a significant amount of genetic diversity exists within and among each of these populations. The above-mentioned accessions of sugar beet displayed more variation than sugar beet cultivars in general (Fritzche et al., 1987; Jung et al., 1993). Fritzsche et al. (1987) used plastid DNA for their analysis, which is much more conservative compared with nuclear DNA and much less prone to rapid evolutionary change compared to morphological changes (Fritzsche et al., 1987). Jung et al. (1993) used modern commercial sugar beet cultivars with monogerm seed and $\mathrm{O}$ type cytoplasm, each of which was introduced to most sugar beet cultivars through single genetic sources.

Results from these investigations demonstrate that table beet inbred lines from the University of Wisconsin Table beet Breeding Program are genetically distinct from standard table beet germplasm, likely because of their origin from an introgression program designed to incorporate sugar beet genes. Despite $>10$ generations of backcrossing to table beet following the initial introgression of sugar beet genes into table beet, the distinct clustering of these two groups of germplasm may be attributed to linkage drag and restricted recombination in certain regions of the beet genome. Characterization of sugar beet-specific genomic regions retained in inbred lines of table beet may shed additional light on the value of sugar beet genes in table beet improvement.

\section{Literature Cited}

Abegg F.A. 1936. A genetic factor for the annual habit in beets and linkage relationship. J. Agr. Res. 53:493-511.

Beebe S.E., I. Ochoa, P.W. Skroch, J. Nienhuis, and J. Tivang. 1995. Genetic diversity among common bean breeding lines developed for central America. Crop Sci. 35:1178-1183.

Buttler, K.P. 1977. Variation in wild populations of annual beet (Beta, Chenopodiaceae). Plant Systematics Evol. 128:123-136.

dos Santos, J.B., J. Nienhuis, P.W. Skroch, J. Tivang, and M. Slocum. 1994. Comparison of RAPD and RFLP genetic markers in determining genetic similarity among Brassica oleracea L. genotypes. Theor. Appl. Genet. 87:909-915.

Eagen, K.A. and I.L. Goldman. 1996. Assessment of RAPD marker frequencies over cycles of recurrent selection for pigment concentration and percent solids in red beet (Beta vulgaris L.). Mol. Breeding 2:107115.

Ecke, W. and G. Michaelis. 1990. Comparison of chloroplast and mitochondrial DNA from five morphologically distinct Beta vulgaris cultivars: Sugarbeet, fodder beet, beet root, foliage beet, and Swiss chard. Theor. Appl. Genet. 79:440-442.

Excoffier, L., P.E. Smouse, and J.M. Ouattro. 1992. Analysis of molecular variance inferred from metric distances among DNA haplotypes: Application to human mitochondrial DNA restriction data. Genetics 131:476491.

Fischer, H.E. 1989. Origin of the 'Weisse Schlesische Rube' (white Silesian beet) and resynthesis of sugarbeet. Euphytica 41:75-80.

Ford Lloyd, B.V. 1995. Sugarbeet, and other cultivated beets, p. 35-40. In: J. Smartt and N.W. Simmonds (eds.). Evolution of crop plants. Longman Scientific \& Technical, Essex, U.K.

Frese, L. and T. van Hintum. 1989. The international data base for Beta, p. 17-35. In: International crop network. Ser 3. Intl. Board Plant Genet. Resources, Rome.

Fritzsche, K., M. Metzlaff, R. Melzer, and R. Hagemann. 1987. Comparative restriction endonuclease analysis and molecular cloning of plastid DNAs from wild species and cultivated varieties of the genus Beta (L.). Theor. Appl. Genet. 74:589-594.

Goldman, I.L. 1996. Inbred line and open-pollinated population releases 
from the University of Wisconsin beet breeding program. HortScience 31:880-881.

Gower, J.C. 1972. Measurement of taxonomic distance and their analysis, p. 1-24. In: J.S. Weiner and J. Huizinga (eds.). The assessment of population affinities in man. Clarendon Press, Oxford, U.K.

Jung, C., K. Pillen, S. Fahr, and A.E. Melchinger. 1993. Phylogenetic relationships between cultivated and wild species of the genus Beta revealed by DNA “fingerprinting.” Theor. Appl. Genet. 86:449-457.

Long, J.G. 1986. The allelic correlation structure of Gainj-and Kalamspeaking people. I. The estimation and interpretation of Wright's Fstatistics. Genetics 112:627-647.

McFarlane, J.S. 1993. The Savitsky story. J. Sugar Beet Res. 30:1-36.

Mita, G., M. Dani, P. Casciari, A. Pasquali, E. Selva, C. Minganti, and P. Piccardi. 1991. Assessment of the degree of genetic variation in beet based on RFLP analysis and the taxonomy of Beta. Euphytica 55:1-6.

Nagamine, T., J.P. Caty, and B.V. Ford-Lloyd. 1989a. Phenotypic polymorphism and allele differentiation of isozymes in folder beet, multigerm sugar beet and monogerm sugar beet. Theor. Appl. Genet. 77:711-720.

Nagamine, T., G.A. Todd, K.P. McCann, H.J. Newbury, and B.V. FordLloyd. 1989b. Use of restriction fragment length polymorphism to fingerprint beets at the genotype and species level. Theor. Appl. Genet. 78:847-851.

Owen, F.V. 1945. Cytoplasmically inherited male-sterile in sugar beets. J.
Agr. Res. 70:423-440.

Shen, Y., H.J. Newbury, and B.V. Ford-Lloyd. 1996. The taxonomic characterisation of annual Beta germplasm in a genetic resources collection using RAPD markers. Euphytica 91:205-212.

Skroch, P.W. and J. Nienhuis. 1995. Qualitative and quantitative characterization of RAPD variation among snap bean (Phaseolus vulgaris L.) genotypes. Theor. Appl. Genet. 91:1078-1085.

Skroch, P.W., J. Tivang, and J. Nienhuis. 1992. Analysis of genetic relationship using RAPD marker data. Applications of RAPD technology to plant breeding, p 26-29. Joint Plant Breeding Symp. Ser., Amer. Soc. Hort. Sci.-Crop Sci. Soc. Amer., Madison, Wisc.

Smith, G.A. 1987. Sugar beet, p. 577-625. In: W.R. Fehr (ed.). Principles of cultivar development. vol. 2. Crop species. MacMillan, New York.

Spooner, D.M., J.G. Tivang, J. Nienhuis, J.P. Miller, D.S. Douches, and A.M. Contreras. 1995. Comparison of four molecular markers in evaluating accessions of the wild potato relatives Solanum section Etuberosum (subgenus potato). Theor. Appl. Genet. 92:532-540.

Tivang, J., P.W. Skroch, J. Nienhuis, and N. DeVos. 1996. Randomly amplified polymorphic DNA (RAPD) variation among and within artichoke (Cynara scolymus L.) cultivars and breeding populations. J. Amer. Soc. Hort. Sci. 12:783-788.

Young, F.W. and R.M. Hamer. 1987. Multidimensional scaling: History, theory, and applications. Lawrence Erlbaum Assoc., Hillsdale, N.J. 